\title{
A case report of suicidal behavior related to subclinical hyperthyroidism
}

\author{
This article was published in the following Dove Press journal: \\ Neuropsychiatric Disease and Treatment \\ 17 April 2014 \\ Number of times this article has been viewed
}

\author{
Soo-Hyun Joo \\ Jong-Hyun Jeong \\ Seung-Chul Hong \\ Department of Psychiatry, St Vincent's \\ Hospital, College of Medicine, The \\ Catholic University of Korea, Suwon, \\ Korea
}

\begin{abstract}
Abnormalities in thyroid function are associated with many psychiatric symptoms. We present a report of a 15-year-old girl who was admitted to the psychiatry inpatient unit with symptoms of suicidal behavior, irritability, and impulsivity. One year previously, she had become more short-tempered, and had started to cut her wrists impulsively. Laboratory tests revealed subclinical hyperthyroidism. She was treated with anxiolytic and antithyroid drugs, and her suicidal ideation and irritability resolved. This case demonstrates that subclinical hyperthyroidism can be associated with suicidal behavior as well as overt hyperthyroidism. Early intervention is required to prevent suicidal behavior in patients with subclinical hyperthyroidism.
\end{abstract}

Keywords: suicidal behavior, subclinical hyperthyroidism, anxiolytics

\section{Introduction}

Hyperthyroidism may be overt (defined as low serum thyroid-stimulating hormone [TSH] and high serum thyroid hormone concentrations) or subclinical (defined as a subnormal serum TSH concentration and normal thyroid hormone concentration). The prevalence of subclinical hyperthyroidism in the worldwide community varies from $0.7 \%$ to $12.4 \%$. Overt hyperthyroidism and the overall prevalence of hyperthyroidism, which is approximately $1.3 \%$, increases to $4 \%-5 \%$ in older women. ${ }^{1}$ Abnormalities in thyroid function are associated with many psychiatric symptoms. Patients with hyperthyroidism have symptoms of fatigue, insomnia, nervousness, labile moods, and dysphoria. Several studies have reported that the overall prevalence of a psychiatric disorder in hyperthyroidism is around $10 \%{ }^{2}$ There are many reports about patients with overt hyperthyroidism accompanied by psychiatric symptoms, but few reports of patients with subclinical hyperthyroidism..$^{3-7}$ We present a case of a 15-year-old female patient who was admitted to the psychiatry inpatient unit with suicidal behavior resulting from subclinical hyperthyroidism.

\section{Case report}

A 15-year-old girl, accompanied by her parents, visited our outpatient clinic presenting with symptoms of suicidal behavior, irritability, and impulsivity. She was in her first year of high school and an only child. Her premorbid personality was calm and introspective. She underwent normal development, fulfilled her school responsibilities, and fulfilled her work obligations in a satisfactory manner. She had a fair relationship with her parents, and had neither a previous medicosurgical nor a neuropsychiatric history.
Correspondence: Jong-Hyun Jeon

93 Jungbu-Daero, Department of Psychiatry, St Vincent's Hospital, College of Medicine, The Catholic University of Korea, Suwon, 442-723, Korea

Tel +850312497150

Fax +850312486758

Email anton3@catholic.ac.kr 
One year previously, she had demonstrated hostility toward her parents because they had refused to let her study abroad. At that time, she developed suicidal impulsivity, such as attempting to jump from the twelfth floor apartment veranda. Eight months earlier, she began to argue frequently with a friend at her school. She became increasingly more irritable, and impulsive. After her private tutor criticized her inattentive behavior, she cut her wrist with a knife. After hospitalization, the patient was irritable, hostile, and impulsive. She was started on buspirone at $20 \mathrm{mg}$ daily to decrease her symptoms.

Physical examination, blood testing including a complete blood cell count, and an electroencephalogram were normal. However, she had subclinical hyperthyroidism as evidenced by a normal free T4 (fT4) $(1.410 \mathrm{ng} / \mathrm{dL})$, normal T3 $(1.390 \mathrm{ng} / \mathrm{mL})$, and low TSH $(0.006 \mu \mathrm{IU} / \mathrm{mL})$ in a serum thyroid function test (TFT).

After 3 days, she demonstrated sweating and weight loss of about $4 \mathrm{~kg}$. On the tenth day after admission, follow-up TFT revealed high fT4 $(2.040 \mathrm{ng} / \mathrm{dL})$ and low TSH $(0.005 \mu \mathrm{IU} / \mathrm{mL})$. These findings confirmed the clinical diagnosis of hyperthyroidism. We consulted with the endocrinology department, and an additional serum assay and thyroid scan were performed. This testing revealed elevated T3 $(2.010 \mathrm{ng} / \mathrm{mL})$, antimicrosomal antibody $(79.400 \mathrm{IU} / \mathrm{mL}$; normal range, $<30.000 \mathrm{IU} / \mathrm{mL}$ ), and thyrotrophin-binding inhibiting immunoglobulin (TBII) levels $(8.410 \mathrm{IU} / \mathrm{L}$; normal range, $<1.750 \mathrm{IU} / \mathrm{L}$ ) and a normal thyroglobulin $\mathrm{Ab}$ level ( $<20 \mathrm{IU} / \mathrm{mL}$; normal range, $<40 \mathrm{IU} / \mathrm{mL}$ ) (Table 1). A Tc-99m thyroid scan showed mildly and diffusely enlarged thyroid glands with inhomogeneous uptake and warm or hot nodules at both lobes, suggesting nodular toxic goiter. The patient was started on methimazole at a dose of $10 \mathrm{mg}$ daily while the buspirone ( $20 \mathrm{mg}$ daily) was continued. About 7 days after starting the methimazole, the patient showed less irritability, improved impulse control, decreased distractibility, and exhibited no suicidal behavior. Follow-up TFT after 4 weeks of hospitalization revealed a decreased fT4 level $(1.560 \mathrm{ng} / \mathrm{dL})$, but it was still abnormal compared with the most recent test (Table 1). After 4 weeks of hospitalization, the patient was discharged. After discharge, she visited our psychiatric and endocrinological clinic routinely. She continued to be treated with $20 \mathrm{mg} /$ day of buspirone and $10 \mathrm{mg} /$ day of methimazole, and showed no irritability, impulsivity or suicidal behavior.

\section{Discussion}

This report describes a patient with irritability, impulsivity, and suicidal behavior with no physical symptoms. She was admitted to the psychiatric inpatient unit. After physical examination, she was initially diagnosed with subclinical hyperthyroidism that subsequently progressed to overt hyperthyroidism.

Hyperthyroidism enhances the $\beta$-adrenergic receptormediated effects of catecholamines by increasing the density and sensitivity of the receptors in peripheral tissues as well as in the brain. ${ }^{8}$ Our findings are inconsistent with those of a relatively recent large cohort study in Sweden, which concluded that patients treated for hyperthyroidism did not have an increased risk of suicide. ${ }^{9}$ Overactivity of the adrenergic system may explain the similarity between the clinical presentations of hyperthyroidism and manic episodes or anxiety disorder. ${ }^{10}$

A notable feature of this case is that, despite the fact that her hyperthyroidism was subclinical, the patient had psychiatric symptoms of hyperthyroidism such as irritability, impulsivity, and suicidal behavior. These findings are consistent with reports showing that patients with subclinical hyperthyroidism have symptoms resembling those of patients with overt hyperthyroidism, with depression, anxiety, and physical symptoms. ${ }^{11,12}$ Therefore, although this patient's serum TFT revealed subclinical hyperthyroidism, her psychiatric symptoms and thyroid function appeared to be closely correlated.

The major antithyroid drugs are methimazole, carbimazole, and propylthiouracil. Their principal action is to inhibit the organification of iodide and coupling of iodothyronines, finally inhibiting the synthesis of thyroid hormones. ${ }^{13}$ Psychiatric medications such as lithium, antipsychotics, and anxiolytics can be used symptomatically and situationally. ${ }^{14}$

Table I Follow-up data of thyroid function and immunoglobulin tests

\begin{tabular}{lllllll}
\hline & Admission & I0 days & I month & 3 months & 6 months & Normal range \\
\hline TSH $(\mathrm{ulU} / \mathrm{mL})$ & 0.006 & 0.005 & 0.001 & 2.655 & 1.170 & $0.350-4.940$ \\
TT4 $(\mathrm{ng} / \mathrm{mL})$ & 1.410 & 2.04 & 1.56 & 0.72 & 1.09 & $0.7-1.48$ \\
T3 $(\mathrm{ng} / \mathrm{mL})$ & 1.390 & 2.01 & & 0.96 & 1.37 & $0.58-1.59$ \\
TBII $(\mathrm{IU} / \mathrm{L})$ & & 8.41 & & 3.52 & 1.09 & $<1.75$ \\
\hline
\end{tabular}

Abbreviations: TSH, thyroid stimulating hormone; fT4, free T4; TBIl, thyrotrophin binding inhibiting immunoglobulins. 
In the present case, we administered the anxiolytic buspirone to control the patient's symptoms such as nervousness and irritability, and we added the antithyroid drug, methimazole after diagnosing the patient with overt hyperthyroidism. After 3 weeks of methimazole treatment, her serum thyroid hormones did not show remarkable change, with the exception of a mildly decreased fT4. However, the patient's irritability, impulsivity, and suicidal behavior decreased along with the buspirone use.

In conclusion we have reported a case of subclinical hyperthyroidism-related suicidal behavior. Based on our report and a literature review, subclinical hyperthyroidism should be considered as a possible cause of suicidal behavior.

\section{Disclosure}

The authors report no conflicts of interest in this work.

\section{References}

1. Hollowell JG, Staehling NW, Flanders WD, et al. Serum TSH, T(4), and thyroid antibodies in the United States population (1988 to 1994): National Health and Nutrition Examination Survey (NHANES III). J Clin Endocrinol Metab. 2002;87:489-499.

2. Bauer M, Goetz T, Glenn T, Whybrow PC. The thyroid-brain interaction in thyroid disorders and mood disorders. J Neuroendocrinol. 2008;20(10):1101-1014.
3. Dietch JT. Diagnosis of organic anxiety disorders. Psychosomatics. 1981;22:661-665.

4. Katerndahl DA, Vande Creek L. Hyperthyroidism and panic attacks. Psychosomatics. 1983;24:491-496.

5. Young LD. Organic affective disorder associated with thyrotoxicosis. Psychosomatics. 1983;25:490-492.

6. Folks DG. Organic affective disorder and underlying thyrotoxicosis. Psychosomatics. 1984;25:243-244.

7. Rao MG, Rohilla J, Varambally S, Raveendranathan D, Venkatasubramanian G, Gabgadhar BN1. Hyperthyroidism presenting as mixed affective state: a case report. Gen Hosp Psychiatry. 2012;34:703.

8. Mason GA, Bondy SC, Nemeroff CB, Walker CH, Prange AJ Jr. The effects of thyroid state on beta-adrenergic and serotonergic receptors in rat brain. Psychoneuroendocrinology. 1987;12(4):261-270.

9. Abraham-Nordling M, Lönn S, Wallin G, et al. Hyperthyroidism and suicide: a retrospective cohort study in Sweden. Eur J Endocrinol. 2009;160(3):437-441.

10. Charney DS. Neuroanatomical circuits modulating fear and anxiety behaviors. Acta Psychiatr Scand Suppl. 2003;(417):38-50.

11. Gulseren S, Gulseren L, Hekimsoy Z, Cetinay P, Ozen C, Tokatiloglu B. Depression, anxiety, health-related quality of life, and disability in patients with overt and subclinical thyroid dysfunction. Arch Med Res. 2006;37(1):133-139.

12. Biondi B, Palmieri EA, Fazio S, et al. Endogenous subclinical hyperthyroidism affects quality of life and cardiac morphology and function in young and middle-aged patients. J Clin Endocrinol Metab. 2000;85(12):4701-4705.

13. Weetman AP. Graves' disease. $N$ Engl J Med. 2000;343:1236-1248.

14. Bunevicius R, Prange AJ Jr. Psychiatric manifestations of Graves' hyperthyroidism. CNS Drugs. 2006;20(11):897-909.
Neuropsychiatric Disease and Treatment

\section{Publish your work in this journal}

Neuropsychiatric Disease and Treatment is an international, peerreviewed journal of clinical therapeutics and pharmacology focusing on concise rapid reporting of clinical or pre-clinical studies on a range of neuropsychiatric and neurological disorders. This journal is indexed on PubMed Central, the 'PsycINFO' database and CAS.

\section{Dovepress}

The manuscript management system is completely online and includes a very quick and fair peer-review system, which is all easy to use. Visit http://www.dovepress.com/testimonials.php to read real quotes from published authors. 